\title{
Budget Institutions in Low-Income Countries: Lessons from G-20
}




\section{Budget Institutions in Low-Income Countries: Lessons from G-20}

Sanjeev Gupta and Sami Ylaoutinen 


\title{
IMF Working Paper
}

Fiscal Affairs Department

\section{Budget Institutions in Low-Income Countries: Lessons from G-20}

\author{
Prepared by Sanjeev Gupta and Sami Ylaoutinen
}

Authorized for distribution by Sanjeev Gupta

September 2014

\section{This Working Paper should not be reported as representing the views of the IMF.} The views expressed in this Working Paper are those of the author(s) and do not necessarily represent those of the IMF or IMF policy. Working Papers describe research in progress by the author(s) and are published to elicit comments and to further debate.

\begin{abstract}
This paper presents twelve budget institutions that can support planning and delivery of credible fiscal strategies in the fiscal policy-making process. The resulting framework is applied to seven low-income countries and the status of their budget institutions compared to the G-20 advanced and emerging market economies. The paper then presents recommendations for designing and implementing appropriate fiscal strategy for lowincome countries. Particular attention is paid to prioritization and sequencing of reform efforts.
\end{abstract}

JEL Classification Numbers: H60, H61, H83

Keywords: Low Income Countries, Budget Institutions, Budget Reforms

Author's E-mail address: sgupata@,imf.org; sami.ylaoutinen@vm.fi 
I. Introduction

II. Budget Institutions for Credible Fiscal Strategy.....

A. Understanding the Fiscal Outlook and Challenges ........................................... $\frac{7}{7}$

B. Formulating a Credible Fiscal Strategy .......................................................

C. Implementing the Fiscal Strategy ................................................................

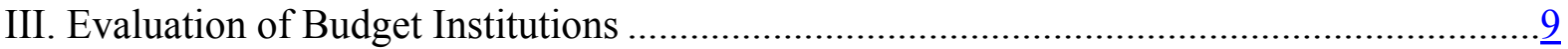

A. Understanding the Fiscal Outlook and Challenges .........................................

B. Developing a Credible Fiscal Strategy ......................................................... $\frac{14}{16}$

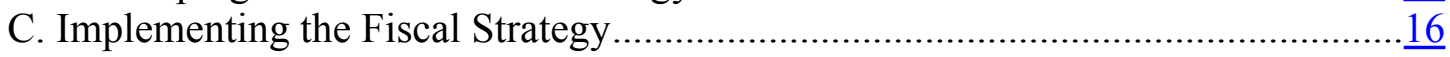

IV. Strengthening Budget Institutions in low-income countries: Priorities for Institutional

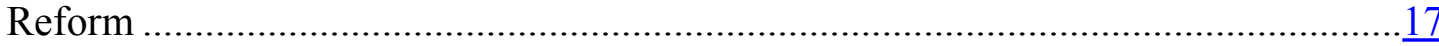

A. Prioritizing Reform Efforts ....................................................................... $\frac{17}{21}$

B. Priorities for Institutional Reform for Low-Income Countries ...........................

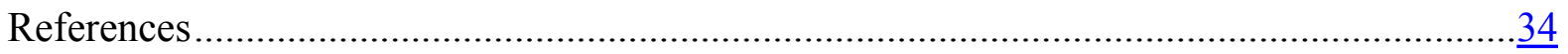

Figures

1. Budget Planning and Execution in Low-Income Countries. ............................................ 5

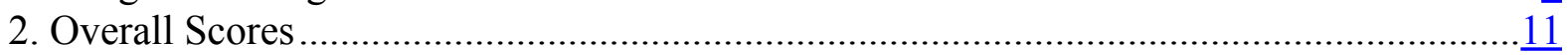

3. Budget Institution Scores by Country and Country Group..........................................12

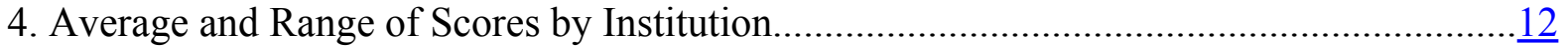

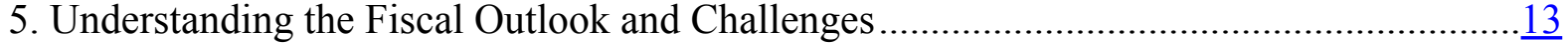

6. Formulating a Credible Fiscal Strategy. ............................................................ 15

7. Implementing the Fiscal Strategy through the Budget Process ......................................16

Boxes

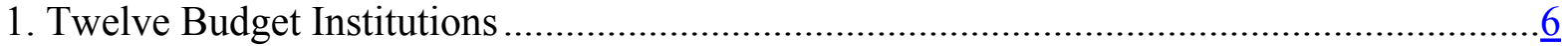

2. Methodology for the Evaluation ....................................................................... 10

3. What can be learned from advanced countries about the prioritization and sequencing of reform of budgetary institutions in developing countries? .................................... 19

Appendixes

I. Budget Institutions Evaluation Framework ..........................................................24

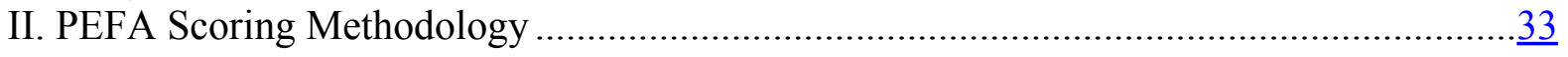




\section{INTRODUCTION ${ }^{1}$}

1. All countries need to ensure fiscal credibility and sustainability. This note presents a framework of budget institutions needed to support countries' fiscal efforts at three key stages of policy making (i) understanding the fiscal outlook and challenges; (ii) formulating a credible fiscal strategy; and (iii) implementing that strategy. ${ }^{2}{ }^{3}$ While originally developed to analyze budget institutions in the G-20 countries, this framework has been subsequently applied to a wider group of countries seeking either fiscal consolidation or overall fiscal discipline.

2. The note is structured as follows. Section II presents twelve budget institutions that can support planning and delivery of credible fiscal strategies at three key stages of the fiscal policy-making process. Section III applies the framework to seven low-income countries and compares the status of their budget institutions to the G-20 advanced and emerging market countries. ${ }^{4}$ This allows a comparison of weaknesses and strengths of country groups' budget institutions across country groups. ${ }^{5}$ Section IV presents recommendations for designing and implementing appropriate fiscal strategy across countries, particularly in low-income countries. Particular attention is paid to prioritization and sequencing of reform efforts. Appendix I presents the full details of the institutional framework.

\section{BUdGet InStitutions FOR CREDIBLE Fiscal STRATEGY}

\section{While many factors affect the behavior of public finances, a well established body of theoretical and empirical analysis shows that budget institutions are important determinants of fiscal outcomes. This evidence covers different geographical regions and countries with varing political set-ups and income levels. ${ }^{6}$}

\footnotetext{
${ }^{1}$ We are grateful to Rachel Wang for research assistance, Richard Allen for assistance on box 3 and section IV as well as participants of UNU-WIDER conference on "Institutional Reforms for Transformation, Inclusion, and Sustainability", June 29-30, Hanoi.

${ }^{2}$ See Olden et al. (2010), IMF (2014).

${ }^{3}$ Budget institutions can be defined in broad terms as the laws, procedures and conventions that influence budgetary decision making and governance.

${ }^{4}$ Advanced: Australia, Canada, France, Germany, Italy, Japan, Korea, UK, US; Emerging Market: Argentine, Brazil, China, India, Indonesia, Mexico, Russia, South Africa, Saudi Arabia, Turkey; Low income: Bolivia, Kenya, Mozambique, Myanmar, Uganda, Vietnam, Zambia.

${ }^{5}$ Country-specific scores are not presented.

${ }^{6}$ See, for example, von Hagen (1992), von Hagen and Harden (1996), Hallerberg et al. (2009), Hallerberg and Yläoutinen (2010) for Europe, Alesina et al. (1999), de Haan et al. (1999), Filc and Scartascini (2007) for Latin America; Gollwitzer (2011) for Africa, Cabezón (2008) for Sub-Saharan heavily indebted countries and DablaNorris et al. (2010) for low-income countries.
} 
4. Strong institutions can improve fiscal performance by highlighting the need for sustainable policies, exposing the full cost of public interventions, emphasizing collective responsibility over sectoral interests, and raising the cost of deviating from stated fiscal objectives. This suggests that governments should, as part of their fiscal strategy, consider the adequacy of the structures, rules and procedures that govern the formulation, passage, and execution of their budgets

\section{Since the strength of budget} institutions impacts fiscal outcomes, institutional gaps are likely to be associated with weaknesses in fiscal outcomes. Figure 1 presents the extent to which the low-income countries have seen differences between the final outturn and the original, approved budget in (i) aggregate expenditure, (ii) composition of expenditure and (iii) aggregate revenues. Score "A" means that the deviations from the original budget have been rare and small, whereas score "D" means that deviations have been frequent and large. ${ }^{7}$

\section{As perhaps expected, the} deviations from the original budget have been substantial in low-income countries. This is particularly the case with the allocation of expenditure, although the size of final expenditure seems to have differed quite markedly from the original budgets. This implies shortcomings both in the budget planning and execution which, in turn, may have a link to institutional

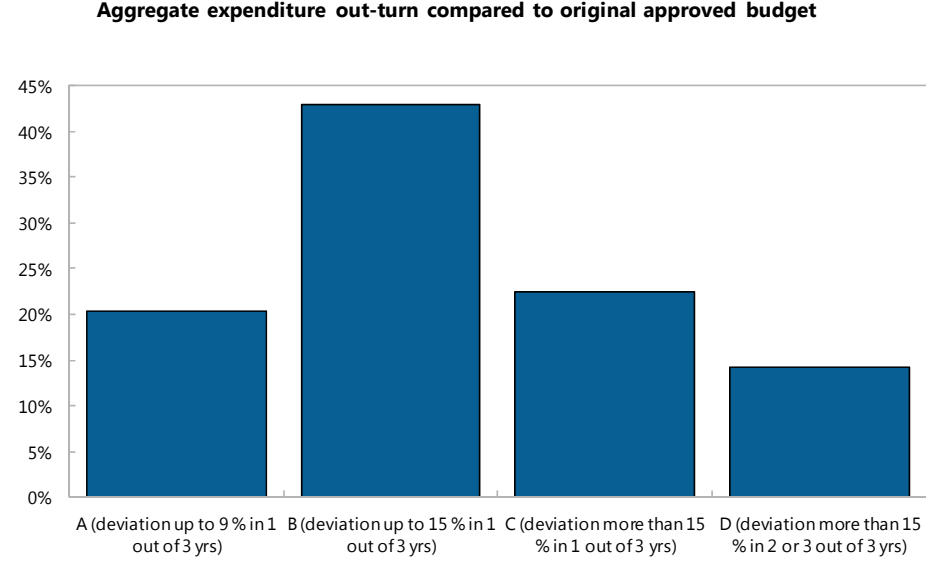

Composition of expenditure out-turn compared to original approved budget

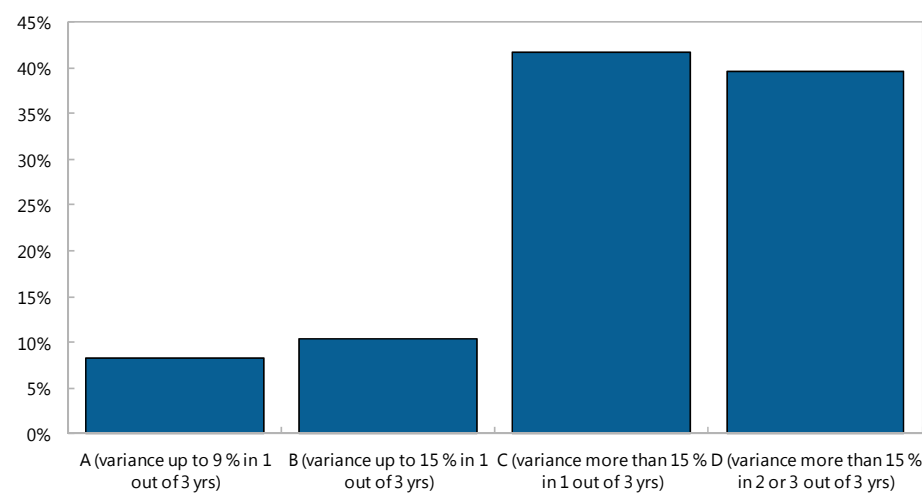

Source: PEFA Database (50 countries). Percentages show the share of countries who received the score in question.

\footnotetext{
${ }^{7}$ The figure is compiled using the data and scoring methodology of PEFA framework (see appendix II and www.pefa.org for further details). For a more discussion about PEFA assessments and results, see de Renzio (2009) and (2013).
} 


\section{The framework presented here allows identification of such institutional}

weaknesses lie. This section identifies twelve budgetary institutions and their key design features that can support planning and delivery of credible fiscal strategies at three key stages of the fiscal policy-making process (Box 1$)^{8}$ :

- $\quad$ understanding the fiscal outlook and challenges;

- $\quad$ formulating a credible fiscal strategy; and

- $\quad$ implementing that strategy through the budget process.

\section{Box 1. Twelve Budget Institutions}

A. Understanding the Fiscal Outlook and Challenges

1. Fiscal Reporting

2. Macroeconomic and Fiscal Forecasting

3. Fiscal Risk Management

4. Independent Fiscal Agency

B. Formulating a Credible Fiscal Strategy

5. Fiscal Objectives and Rules

6. Medium-term Budget Framework

7. Performance Orientation

8. Intergovernmental Fiscal Arrangements

C. Implementing the Fiscal Strategy

9. Budget Unity

10. Top-down Budgeting

11. Parliamentary Budget Approval

12. Budget Execution

Source: IMF (2014)

8. The institutions included in the framework have been identified on the basis of their ability to support planning and implementing a credible fiscal strategy. However, while this framework presents an informative way to analyze shortcomings and related reform needs in countries' fiscal frameworks, it should not be viewed as a generic guide to budget institution reforms. When applying this approach to low-income countries, attention has to be paid to sequencing of reforms, which depends on country specific circumstances, including on their capacity to implement them. These issues will be discussed in detail in section IV.

\footnotetext{
${ }^{8}$ For a more detailed discussion, see Olden et al. (2010) on which the discussion here is also based.
} 


\section{A. Understanding the Fiscal Outlook and Challenges}

\section{A pre-requisite for a credible fiscal strategy is a clear understanding of the} current fiscal position and a realistic view of the medium-term fiscal outlook. Full awareness of the current state and future evolution of the public finances is particularly important today when many countries face a complex and uncertain macroeconomic and fiscal outlook. In this context, the following institutions are important:

- $\quad$ Fiscal reporting. Fiscal reporting arrangements that provide comprehensive, timely, credible, and transparent information are central to inform decision makers and the public about the state and outlook of the economy. This should include comprehensive and accurate fiscal reporting, including financial statements audited by an independent audit institution and fiscal statistics produced by an independent statistics agency;

- Macroeconomic and fiscal forecasting. A realistic and credible medium-term macroeconomic and fiscal forecast is a starting point for the formulation of a credible fiscal strategy. Ideally, macro-fiscal forecasts should have a multi-year focus, be updated on a frequent basis and cover all fiscal aggregates together with a range of realistic economic assumptions.

- $\quad$ Disclosure and management of fiscal risks. The government's fiscal strategy needs to be robust and take account of risks that threaten the fiscal position. Main fiscal risks (macro-fiscal, guarantees, international commitments, social commitments, publicprivate partnerships, and legal claims) should therefore be disclosed in budget documents together with alternative medium-term budget scenarios. New risks (contingent liabilities in particular) should be subject to similar scrutiny and approval as regular budget appropriations. This is particularly important during times of fiscal stress when the temptation to circumvent expenditure restrictions by resorting to guarantees and other contingent liabilities could become stronger.

- Independent fiscal agencies. Independent fiscal agencies with a clear mandate can help to support the overall credibility of a government's fiscal strategy by assessing the credibility of the forecasts and the government's fiscal performance on a regular basis.

\section{B. Formulating a Credible Fiscal Strategy}

10. The formulation of a credible fiscal strategy can benefit from strong institutional arrangements. In particular, the credibility of a fiscal strategy is enhanced if it is based on comprehensive fiscal objectives, takes a medium-term perspective, connects the funds provided to public entities to their outcomes or outputs and connects together different levels of government. The following four budget institutions are important: 
- $\quad$ Fiscal objectives and rules. Comprehensive, transparent and stable fiscal objectives connect the medium-term fiscal strategy with numerical targets that will guide future decisions and against which performance can be monitored. Some flexibility, either by accounting for the cycle or by including explicit escape clauses can enhance the credibility of fiscal rules.

- $\quad$ Medium-term budget frameworks. Medium-term budget frameworks are crucial to convert those targets into detailed and documented revenue and expenditure plans. Successful medium-term budget frameworks provide binding restrictions on multiyear expenditure and a clear and consistent statement of the government's mediumterm priorities within a total expenditure ceiling. Such frameworks should cover most central government expenditure.

- $\quad$ Performance-oriented budgeting. Performance budgeting - defined as the procedures that strengthen the links between spending on programs and projects and the outcomes or outputs of these programs - provides decision makers with information on how the budget contributes to the government's overall policies. Regular spending reviews can help to provide a strong evidence base for expenditure rationalization

- Intergovernmental fiscal arrangements. Intergovernmental financial arrangements ensure the consistency of the fiscal stance within the different levels of government, and allow coordinating and burden sharing of fiscal policy and spending between layers of government.

\section{Implementing the Fiscal Strategy}

11. Even the most robust consolidation plan can be derailed when confronted with the pressures and realities of the annual budget process. Unless supported by strong institutional arrangements for the preparation, approval, and execution of the budget, there is a risk that actual expenditure will turn out to be higher than forecast, or actual revenue lower than forecast. Four institutions are central in this regard:

- $\quad$ Budget unity. A high degree of budget unity ensures that central government expenditures are authorized under one decision-making process, which consequently makes the control over budget execution more effective. Most central government expenditure should be covered by the central government budget and authorized annually. Also major tax expenditures should be quantified and published.

- A top-down approach to budget preparation. Under a top-down approach, limits on both aggregate and sectoral spending are agreed by the government at an early stage in the budget preparation process. This approach increases the likelihood that the outcome of the annual budget discussions will be consistent with the government's ex ante fiscal objectives and fiscal plan. The earmarking of revenue should be limited 
and all major revenue and expenditure decisions should be taken as a part of the annual budget process.

- $\quad$ Constraints on parliamentary budget approval. While parliament's formal powers over the allocation of public resources varies greatly across countries, experience suggests that pre-budget or budget orientation debates can help create parliamentary ownership of medium-term fiscal objectives in a range of legislative contexts. The political legitimacy of the overall fiscal strategy is further enhanced when parliament endorses the government's medium-term fiscal objectives before considering the government's annual budget proposal. However, greater parliamentary input into the overall fiscal strategy needs to be combined with legislative procedures that promote collective responsibility for its delivery. As in cabinet, voting on the budget in parliament should follow a top-down sequence in which the legislature first approves the main fiscal aggregates, such as the budget balance, total expenditure and total revenue, before voting the allocation of resources to different sectors, ministries, programs, or line items.

- Discipline in budget execution. Effective implementation of a consolidation program requires budget execution procedures that maintain overall fiscal discipline, while recognizing that unexpected events will occur during the course of the budget year. Open-ended or standing appropriations should be kept to a minimum. Overspending against budget totals should require the government to introduce a supplementary budget and, ideally, propose offsetting expenditure cuts. ${ }^{9}$ Carry-over of expenditureenabling budget agencies to exceed annual appropriations - should also be subject to restrictions. To avoid future expenditure room being taken up by binding contracts or future promises, controls on multi-annual commitments should also be in place.

\section{EVALUATION OF BUDGET InSTITUTIONS}

\section{This section includes a discussion on the extent to which the twelve budget} institutions identified in the previous section are in place. This is done by applying an evaluation methodology which allows transforming the institutional features of countries' fiscal frameworks into a set of ratings (see box 2 and appendix I). As mentioned earlier, these ratings are not reported in the paper. ${ }^{10}$ In this context, few caveats are worth mentioning:

- The analysis presents only a snapshot of the state of countries' current budget institutions. Many countries under review are engaged in ambitious reform agendas to

\footnotetext{
${ }^{9}$ Also virements can be used to make in-year adjustments in budget appropriations.

${ }^{10}$ The ratings are derived from assessments made by experts familiar with the institutional set up in these countries.
} 
strengthen their frameworks. Due to the static nature of the analysis, the discussion below does not do justice to these efforts.

- $\quad$ Each institution included in the framework is treated with equal importance, that is, assigned uniform weights. A case could be made that not all institutions are necessarily equally important, particularly from a country-specific point of view. While this is justified, the approach is meant to keep the framework as transparent and simple as possible.

- $\quad$ Finally, the sample of countries under a review is small, only seven low-income countries. While the discussion below gives a good overview on the state of these countries' budget institutions, the results are not necessarily representative of all lowincome countries.

\section{Box 2: Methodology for the Evaluation}

The twelve budget institutions and their key features described in previous section are used to evaluate the institutional strength of each country in the sample. Each key feature is translated into a specific evaluation question. The number of questions by institution varies from three to six, and the assessment consists of 52 questions in total. The questions have been formulated in such a way that they are factually verifiable. A country is given a rating of 0 if the criterion is not met; 1 if the criterion is partly met; and 2 if the criterion is fully met. The evaluation questions and basis for each rating are set out in Appendix 1. For every country, the ratings against each question are averaged to produce an overall score of the strength of each of the twelve institutions. Each of the twelve institutions has the same weight in these averages, regardless of the number of questions used to rate the institution.

Source: Olden et al. (2010)

\section{Based on the institutional scores, the following general observations can be made} (see Figures 1-3):

- As one might expect, the budget institution scores, are lower in low-income countries, compared to emerging market and advanced countries. This applies particularly to understanding and planning stages, where the largest institutional gaps for lowincome countries seem to be. ${ }^{11}$

\footnotetext{
${ }^{11}$ This should not be interpreted to say that low income countries have no weaknesses in budget execution. For example, Andrews (2013), based on PEFA scores, found developing countries had the weakest scores in the budget execution among different stages of the budget process.
} 
- $\quad$ There seems to be a link between strength of institutions and economic development; institutional scores and GDP per capita broadly speaking move together in the country sample. ${ }^{12}$

- Low-income countries score, on average, are the lowest among country-groups in all categories except three, namely top-down budgeting (slightly higher than emerging), parliamentary approval (tied with emerging) and budget unity (tied with emerging markets and advanced), whereas advanced countries score, on average, higher than others in all other categories.

- The variance of scores by institution is generally speaking larger for low-income and emerging market countries, compared to advanced countries indicating large differences between and among countries. ${ }^{13}$ Particularly for understanding and planning stages, many low-income countries scored zero on number of individual institutions indicating that these countries do not have basic arrangements in place.

\section{- Figure 2. Overall Scores}

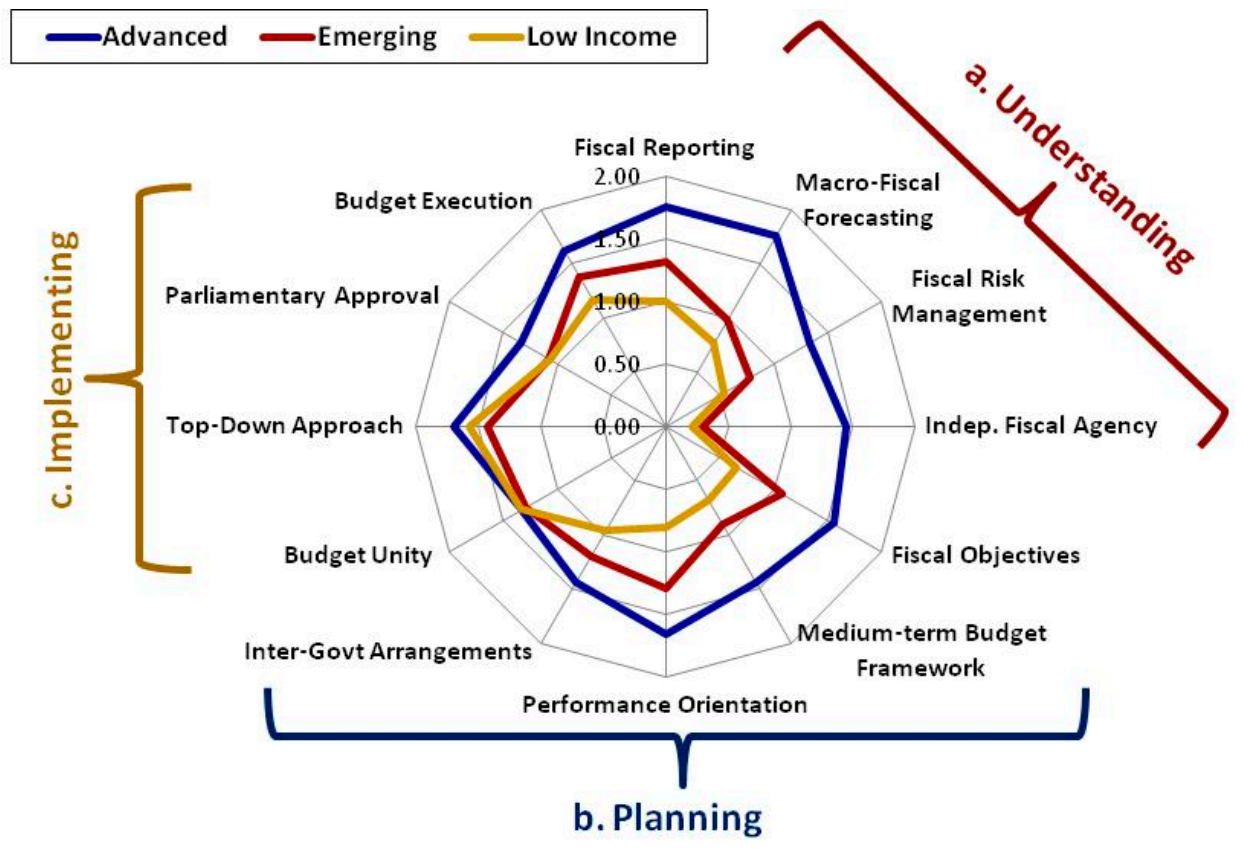

\footnotetext{
${ }^{12}$ Also the recent crisis has played an important role in incentivizing the advanced countries to carry out institutional reforms. As noted in IMF (2014), reforms have been implemented at a rapid pace in advanced Europe in light of the need for fiscal consolidation in the aftermath of the financial crisis, contributing to a growing gap in institutional strength between advanced and emerging G-20 countries.

${ }^{13}$ Here one should note that the sample sizes are different between the country groups: low-income countries (7), emerging market (10) and advanced countries (9).
} 
Figure 3. Budget Institution Scores by Country and Country Group

Figure 4. Average and Range of Scores by Institution
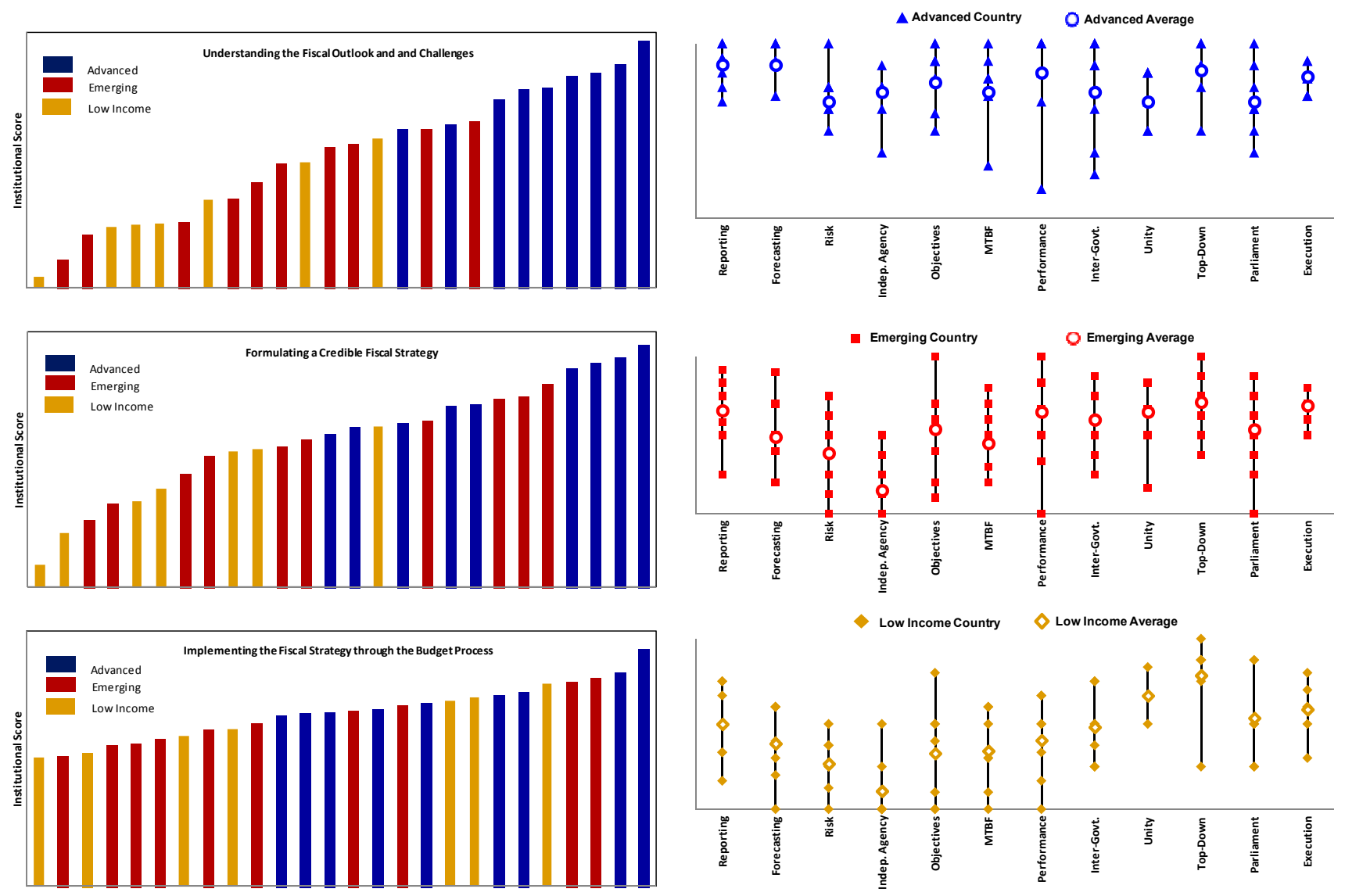

A. Understanding the Fiscal Outlook and Challenges

14. Most low-income countries in the sample seem to have basic fiscal reporting practices in place which should give them reasonable information about the present financial position. However, arrangements related to forecasting future fiscal developments and related risks are less robust. These are the areas where the gaps in the G-20 advanced countries are also most pronounced. 
Figure 5. Understanding the Fiscal Outlook and Challenges
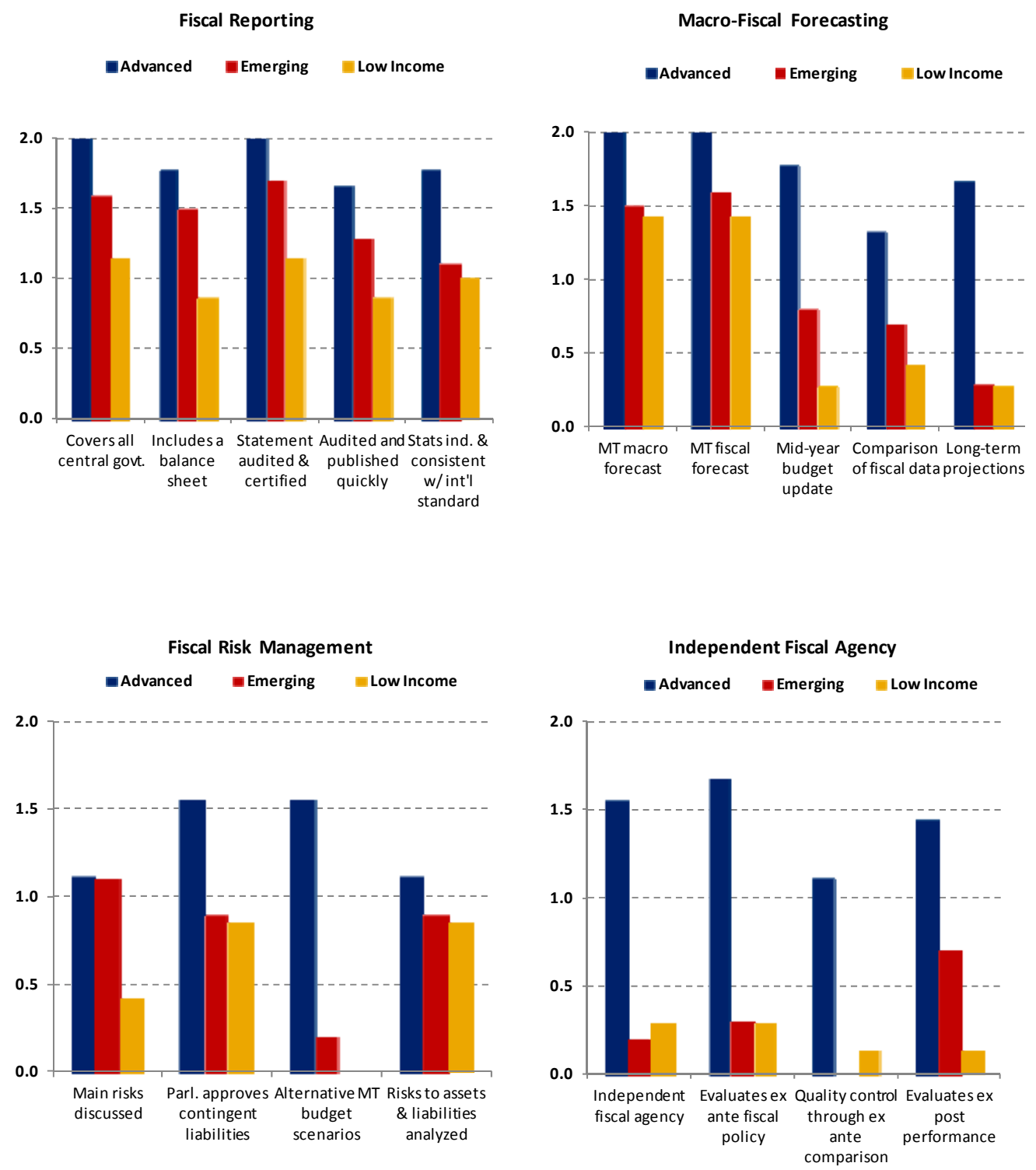

- $\quad$ Fiscal Reporting: All low-income countries produce financial statements which cover at least the budget, and in most countries financial statements are audited by external auditor. Most countries produce a balance sheet, but generally speaking without including all assets and liabilities. About half of the countries produce financial statistics for central and general government but generally not for the whole of the public sector. In almost all countries financial statistics are produced by an independent office but generally not in line with international standards.

- Macroeconomic and Fiscal Forecasting: About a half of the low-income countries publish medium term forecasts in the budget documents with related assumptions but generally speaking without any quality control through ex post comparison of 
previous forecasts with actual outturn of key macroeconomic and fiscal aggregates. Also an update half-way through the budget year, with updated projections of key fiscal variables is missing in almost all countries. Long-term fiscal projections are also a rarity.

- $\quad$ Fiscal Risk Management: Main fiscal risks (macro-fiscal, guarantees, international commitments, social commitments, PPPs, legal claims) are not discussed nor quantified in the budget documents. Also alternative medium-term budget scenarios are not produced. In majority of the countries, the government prepares a mediumterm debt management strategy, including analysis of debt-related risks, but without including asset-related risks (for example changes in the asset values or cash-flow they provide). In almost all countries, parliamentary approval is sought for new guarantees and in very few, for other significant contingent liabilities.

- Independent Fiscal Agency: With some exceptions, countries do not have independent agencies to assess the credibility of the forecasts and the government's fiscal performance on a regular basis.

\section{B. Developing a Credible Fiscal Strategy}

\section{Many institutions related to formulation of a fiscal strategy are relatively}

underdeveloped. Most countries have taken first steps in introducing some medium-term elements in their fiscal management but many challenges remain to be addressed; fiscal objectives and medium-term budget frameworks receive the lowest scores on average among the low-income countries. Also performance orientation is still at its infancy. Finally, intergovernmental financial arrangements are not clearly specified in many countries.

- $\quad$ Fiscal Objectives and Rules: About half of the countries have specified some type of medium-term fiscal objective and regularly report performance against the stated objective. In very few countries, the objective has been enshrined in the law, and in almost all countries, exceptions to the rule are frequent. Fiscal objectives do not accommodate the impact of the business cycle.

- $\quad$ Medium-term Budget Framework: About half of the countries have some type of multi-year estimates for major categories of revenue and expenditure but they constitute only a non-binding restriction to future budgets. No reconciliation of changes in sectoral allocations from year to year is currently produced. Furthermore, budget documents do not present any consolidated summary of the fiscal impact of proposed new revenue and expenditure measures.

- Performance Orientation: About half of the countries include a program classification for information, and only in very few of these form the basis for legislative appropriation. Many countries have established some type of performance targets or objectives but typically these are not systematically monitored. Comprehensive and 
systematic expenditure reviews are rare among the low-income countries in the sample.

- Intergovernmental Fiscal Arrangements: About a half of the countries produce a year-ahead or a medium-term forecast of the budget or the central or federal government but it is typically not broken down into the respective contribution of individual sectors/level of government (budget, social security funds, extra-budgetary funds, local government and state-owned enterprises). Majority of the countries have fiscal rules for sub-national governments in place but without centralized sanctions or enforcement mechanisms. Again, about a half of the countries have a legal framework for coordinating and sharing the burden of fiscal policy between layers of government.

Figure 6. Formulating a Credible Fiscal Strategy
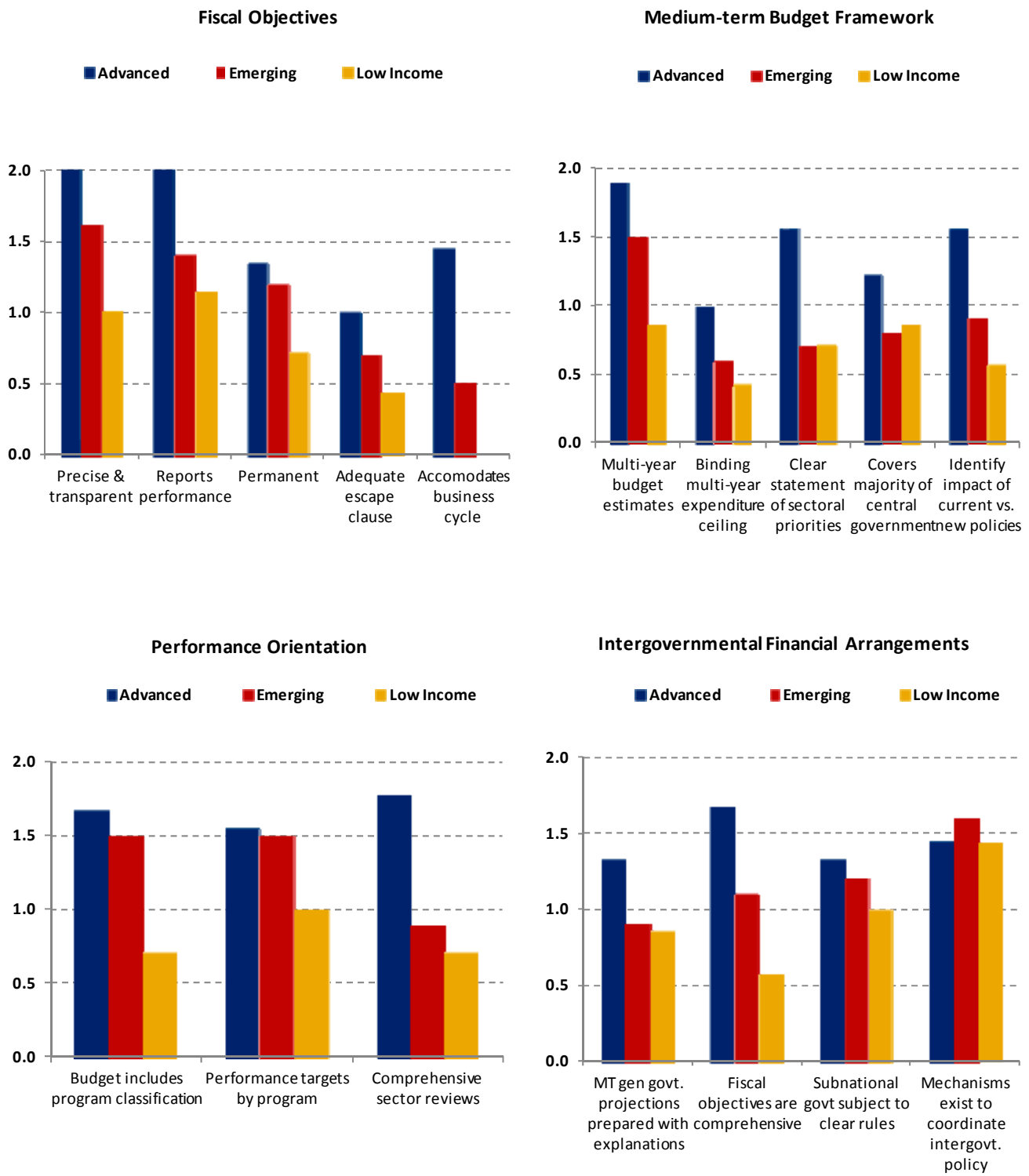


\section{Implementing the Fiscal Strategy}

16. Institutions related to implementing the fiscal strategy emerge as the strongest among the three key stages of the fiscal policy-making process included in the

framework. Gaps in relation to the advanced G-20 countries still persist particularly in topdown budgeting and budget execution. In particular, while it is common to fix the ceilings at the early stages of the budget process, it is equally common that these restrictions are overlooked at the subsequent stages.

Figure 7. Implementing the Fiscal Strategy through the Budget Process
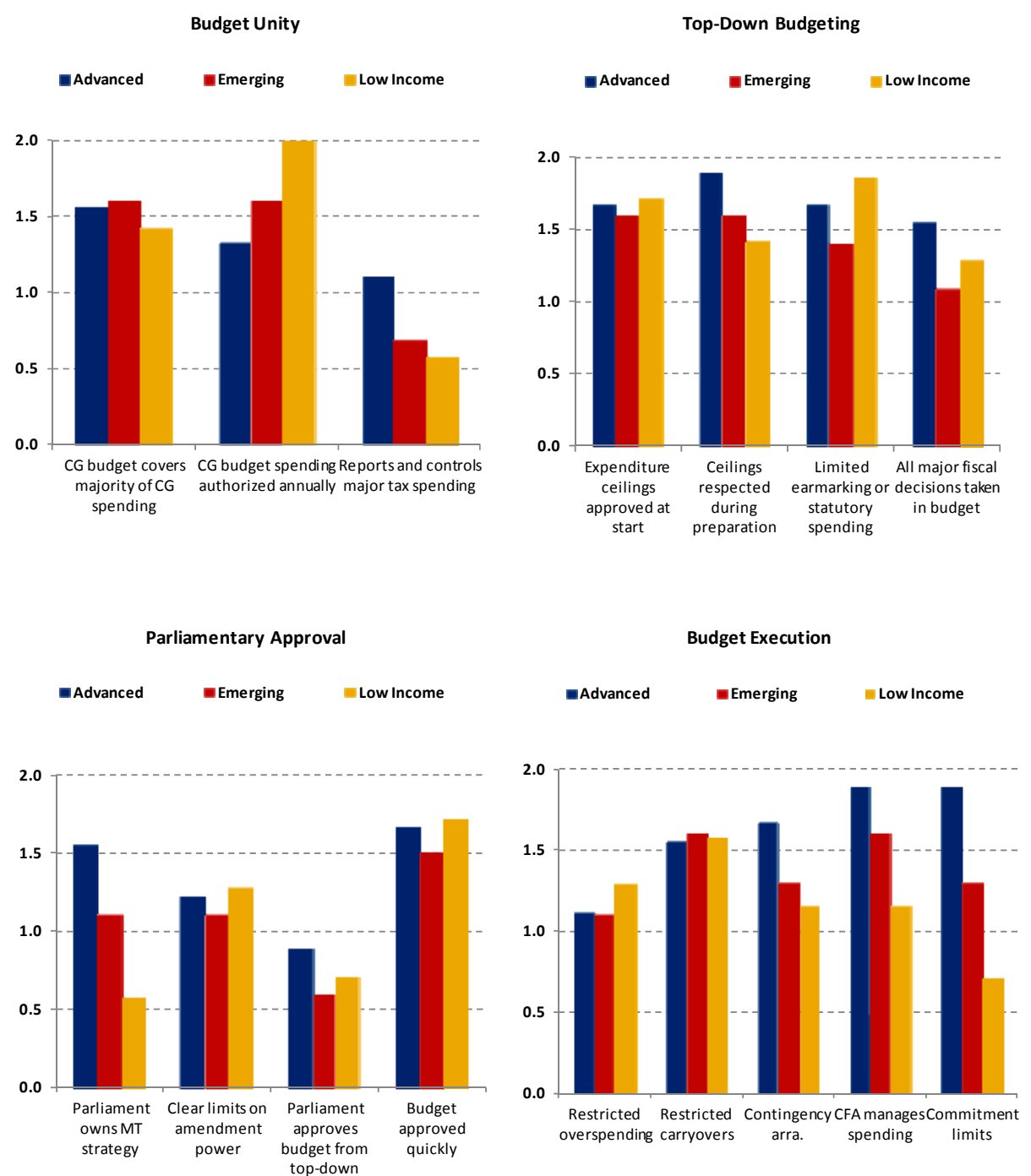

- Budget Unity: Low-income countries receive equal scores on average on budget unity when compared to emerging market and advanced countries. In all of the countries, the budget, unemployment and social security funds or spending cover at least 80 percent, and in many, more than 90 percent of central government expenditure. In all countries more than 90 percent of the budget spending requires annual authorization 
by parliament. However, arrangements regarding tax expenditures are less advanced; while most countries produce an annual quantification of tax expenditures, there is no control on their size.

- $\quad$ Top-down Budgeting: In almost all countries, there are ex ante limits on both aggregate and sectoral or ministerial spending provided in budget submissions, but importantly, in about half of the countries there ceilings are rarely respected. In almost all countries less than 10 percent of central government revenue is subject to earmarking or standing spending commitments. In about half of the countries, major revenue and expenditure decisions are often or sometimes taken outside the budget process.

- $\quad$ Parliamentary Budget Approval: Typically, the parliament does not endorse a medium-term fiscal target or objective. With some exceptions, there are limits on the legislature's right to amend the government's draft budget. In about a half of the countries, the annual budget is not approved in a top-down sequence (i.e. parliament does not first approve an overall annual budget framework for total revenues and total expenditures). Typically, the legislature's right to amend the executive's budget proposal is rather limited. In majority of the countries, there is a legal requirement in place that a budget has to be approved before the start of the fiscal year.

- Budget Execution: Most countries have restrictions in place on overspending during the execution of the annual budget. In particular, most countries require a submission of a supplementary budget to parliament. Typically, carry-overs are not allowed or the government imposes a ceiling on the size of annual carry-over or on carry-over draw-downs. Contingency arrangements for specific expenditure categories exist in all countries but in some cases access criteria to such funds could be specified more clearly. In most countries, the finance minister (the executive) can defer or cut expenditure, without prior approval of parliament, at least up to a certain limit. Finally, all countries lack comprehensive limits or controls on multi-annual expenditure commitments.

\section{Strengthening Budget Institutions in Low-income countries: Priorities FOR INSTITUTIONAL REFORM}

\section{A. Prioritizing Reform Efforts}

17. As is apparent from the discussion above, low-income countries have substantial shortcomings in their budget institutions, which call for continuous reform efforts. Based on the institutional review, the largest institutional gaps currently can be found from understanding and planning stages of the fiscal policy-making process, although some important challenges remain also in the implementation stage. This is in line with the observation made earlier that the composition as well as size of expenditure outturns have 
deviated substantially from the original, approved budgets in low-income countries, indicating problems with budget planning (see figure 1 in Section II). Higher relative scores in the implementation stage may reflect a tradition of administrative and fiscal centralization among the countries in this group.

18. However, designing a reform agenda for low-income countries is a balancing act between ambition and realism. On the one hand, the reinforcing nature of the different institutions underlines the importance of taking a comprehensive approach to institutional reform. Indeed, institutional reforms in the above areas need to be coordinated across the budget stages and between branches and levels of government to maximize their impact on fiscal decision-making and performance. The impact of reform at any one stage of the process on fiscal behavior depends on the integrity of the system as a whole. But on the other hand, the design of a reform agenda has to take into account the low capacity of many lowincome countries to implement reforms, as well as political economy constraints and weak governance systems. Therefore it is not realistic to assume that all deficiencies identified above could be addressed simultaneously. Some prioritization and sequencing will be needed.

19. Indeed, reforms in budget institutions should address particular country-specific problems and should be placed in an appropriate order, i.e., be given the correct priority and sequence. The literature sets out some general principles (e.g., Diamond, 2012, Allen, 2013) but recognizes the difficulty of developing a set of operational rules that is applicable in all countries, in all contexts, and at all times. However, some guidance can be sought from the advanced country experiences (see box 3 ). 


\section{Box 3: What Can Be Learned from Advanced Countries About the Prioritization and Sequencing of Reform of Budgetary Institutions?}

First, reform of budgetary institutions does not proceed on a recognizably predictable path: it is incremental, usually not governed by a grand design, and generally takes a long time (Andrews, 2013). Table below shows how in all three countries - France, the United Kingdom, and the United States - a similar pattern can be observed. First, basic systems of accounting, budgeting, and financial reporting were established according to a uniform set of standards and procedures. After these basic budget elements were in place, countries' moved on to develop more sophisticated PFM practices, such as medium term budget frameworks, performance budgeting and accrual accounting.

Second, advanced countries have tended to approach reform in a logical order, namely that the more basic reforms have been carried out first, and once these procedures have been firmly established, more advanced reform are built on top of them. Such a process may take many years to implement, but by allowing adjustments to be made at all stages is more likely to succeed.

Third, reform is driven by a range of factors and influences, internal and external. The most important factor historically has probably been the influence of economic and financial crises, or sizeable political changes triggered by a change in constitution or new elections. Another critical element is the strength of political leadership. If such strong drivers are absent, reforms are likely to be slower, more cautious and more incremental in nature.

\begin{tabular}{ll}
\hline \multicolumn{1}{c}{ France } & \multicolumn{1}{c}{ United Kingdom } \\
\hline 1791: Accounting Office reporting & 1787: Consolidated Fund \\
to parliament & established \\
1807: Independent "Cour des & 1866: Exchequer and Audit \\
comptes" & Departments Act (established \\
1814-19: First Restoration- Baron & modern budgeting and \\
Louis's reforms & accounting system) \\
1862: Imperial decree on rules for & 1866: Comptroller and Auditor \\
budgeting and treasury single & General established \\
\cline { 2 - 2 }
\end{tabular}

account

1959: Medium-term budget framework for investments 1968: Rationalisation des choix budgetaires (The Rationalization of Budget Decisions) 2001-06: Program budgeting From 2006: Accrual accounting 2008: Full medium-term Budget framework 1960s: Public Expenditure Survey (PES) and Program Assessment Review (PAR) 1980s: Next Steps Program 1990s: Comprehensive multiannual budgeting 1991: Citizen's Charter 1998: Public Service Agreements 2000-04: Resource (accrual) budgeting

United States (Federal)

1776: Treasury Office of Accounts established 1809: Appropriations Act (modified in 1870 and 1874) 1887-89: Consolidated accounting, bookkeeping, reporting procedures (Cockrill Commission) 1894: Dockery Act established Comptroller of the Treasury; consolidated annual statement of revenues and expenditures 1921: Budgeting and Accounting Act established Bureau of the Budget and General Accounting Office 1940: Consolidation of uniform standards and procedures for accounting and reporting 1950: Accounting and Auditing Act

1982: Federal Managers Financial Integrity Act 1990: Chief Financial Officers Act 1993: Government Performance and Results Act 1994: Government Management Reform Act 2010: Government Performance and Modernization Act 


\section{Box 3: What Can Be Learned from Advanced Countries About the Prioritization and Sequencing of Reform of Budgetary Institutions? (concluded)}

Fourth, reforms that are driven by powerful external or internal forces can often take place more rapidly but still require considerable time for their design and implementation. For example, in South Africa, the reforms to the public finance and budgeting system, including establishing a new financial relationship between central, provincial and local governments, took at least 10 years to implement, and are still being developed and refined 20 years later.

Fourth, reforms that are driven by powerful external or internal forces can often take place more rapidly but still require considerable time for their design and implementation. For example, in South Africa, the reforms to the public finance and budgeting system, including establishing a new financial relationship between central, provincial and local governments, took at least 10 years to implement, and are still being developed and refined 20 years later.

Fifth, as Andrews (2013) has pointed out, most reforms are iterative and adaptive, namely they proceed by a series of initiatives and steps, then require adaptation, as experience in implementing the new system is gained, and lessons learned, or if changes in technology require further changes to be made (such as FMIS or debt management systems). Sometimes reform initiatives have not been sufficiently well thought through or run out of political support have been reversed. A dramatic example was the zero-based budgeting reforms in the U.S in the 1960s, and the partial abandonment of the performance-based assessment framework (PART) under the Clinton Administration.

Finally, advanced countries have made adjustments to the organization of their central finance agencies in parallel with and in support of the reforms they have made. Corporate restructuring of the British Treasury, for example, was carried out in the 1960s, early 1990s and early 2010s; and smaller modular or incremental changes in between (Allen, 2013). This has enabled the government to ensure that (i) the core functions of the finance ministry are appropriate to the economic and financial conditions of the time; and (ii) sufficient resources - human and IT - are available to carry out these functions and tasks.

Source: Allen (2013), Note: Measures that established the basic framework of accounting and budgeting are shown above the broken lines; items shown below the lines were introduced later.

\section{Most advanced countries have reached decisions about the sequencing of reform} in a non-structured fashion, but some important guiding principles can be identified:

- It is important to distinguish two kinds of sequencing - first, the order in which different initiatives within an overall PFM reform strategy (e.g., establishing a macrofiscal forecasting unit, a treasury single account; a modern debt management agency) are introduced; and, second, the sequencing of individual tasks and activities within a single component of such a strategy - for example, the steps that are needed to convert the government's accounting and reporting system from a cash basis to an accrual basis, or to establish and make fully operational a unified revenue authority.

- $\quad$ Countries should not attempt too many reforms at one time. If too many reforms are attempted simultaneously, they are unlikely to succeed, e.g., because sufficient 
resources (human and financial) are not available, or the management capacity of the finance ministry is overstretched.

- Important basic elements of a budgeting system need to be put in place first before more advanced elements are incorporated.

- Many countries have tended to underestimate the complexity of the reform process, and the need for careful handling of the implications for resources and staffing and supporting IT systems. A reform that is demanding in terms of skills and resourcessuch as introducing an MTBF, an accrual accounting system, or a TSA—requires strong leadership, the development of a detailed action plan, a dedicated project management and communications team to implement the reform, and the active management of the human resource aspects of the reform. If these factors are given insufficient attention it is possible, if not likely, that the reform will (i) meet with substantial resistance inside and outside the finance ministry; (ii) take longer than expected to implement; (iii) cost more than necessary; and (iv) deliver less than the full expected benefits, or fail completely.

- Reforms also need to take into account the views of stakeholders external to the finance ministry. Strong opposition may build up to reforms from line ministries, the president's office, or consumers of public services. There may also be opposition from managers and staff within the finance ministry.

\section{B. Priorities for Institutional Reform for Low-Income Countries}

\section{In the context of the framework used in this paper, many budget institutions} included in the framework can be seen as prerequisites to others. For example, binding medium term budget frameworks have proved to be a useful and efficient tool for fiscal management in many advanced economies. However, implementing such frameworks is not an easy task: preconditions to a successful binding medium term budget framework include credible and predictable annual budget, accurate medium-term macroeconomic and demographic projections, medium-term fiscal objectives and rules and comprehensive, unified, top-down budget process (Harris et al, 2013).

\section{Indeed, low-income countries should ensure that the basic PFM systems are in} place before attempting to implement more sophisticated arrangements. Given what has been discussed above, what institutional reforms should be seen as a priority? The analysis presented above shows considerable variance in the strengths and weaknesses of budget institutions across and within the low-income countries. Appropriate reform strategies therefore require country-specific reform programs and any generic advice is bound to be incomplete. With this limitation in mind, one can nevertheless highlight some common areas of institutional shortcomings countries should seek to address. 


\section{Understanding the Fiscal Outlook and Challenges}

23. The analysis above revealed that most low-income countries in the sample seem to have basic fiscal reporting practices in place but arrangements related to forecasting future fiscal developments and related risks are less robust. In order to improve understanding of the current and future fiscal position, low-income countries could consider:

- $\quad$ expanding the coverage of their annual financial statements to central government, and further to general government, and ensure that there is a published external audit;

- $\quad$ producing financial statistics by an independent office, in line with international standards;

- $\quad$ including comprehensive information about fiscal risks in their budget documentation, particularly in countries where PPPs, for example, are being used;

- $\quad$ producing and publishing macroeconomic forecasts alongside related assumptions; and updating the forecasts in line with the budget process, and;

- $\quad$ once the forecasting capacity improves, introducing medium-term forecasts with alternative medium-term budget scenarios which would provide policymakers with a better sense of the country-specific vulnerability to uncertainty.

\section{Formulating a Credible Fiscal Strategy}

24. Based on the discussion above, many of the institutions related to formulation of a fiscal strategy seem to be relatively underdeveloped. While most countries have taken first steps in introducing some medium-term elements in their fiscal management, many challenges remain to be addressed. Where appropriate, the low-income countries could consider:

- $\quad$ adopting a medium-term objective, in countries currently without such objective to provide guidance to fiscal planning, and once such objective is in place, regularly report on the fiscal performance against the stated objective;

- $\quad$ in countries without any medium-term fiscal or budget framework, developing a simple framework, which would provide a projection of the fiscal balance, include estimates of government revenues and spending at a more aggregate level, and at the second stage providing guidelines (envelopes) to line ministries to prepare mediumterm spending plans;

- $\quad$ once the prerequisites, such as solid macro-fiscal forecasting, credible budget, topdown budget process and medium-term fiscal objectives are in place, developing the framework into a more binding direction; and 
- $\quad$ ensuring proper interaction between central or federal government and subnational governments, at least by exchanging information regularly on fiscal policy, or ideally putting in place a legal framework for coordinating and sharing the burden of fiscal policy between layers of government.

\section{Implementing the Fiscal Strategy}

25. While the institutions related to implementing the fiscal strategy seem to be the strongest among the three key stages reviewed, important challenges remain. These relate mainly to top-down budgeting and budget execution. In this context, low-income countries could consider

- $\quad$ issuing ex ante limits on both aggregate and sectoral or ministerial spending at an early stage in the budget preparation process, making sure that the size of the limits is realistic;

- $\quad$ changing parliamentary procedures to follow a top-down sequence where the parliament first approves an overall annual budget framework for total revenues and total expenditures, and then discusses the allocation within these totals;

- $\quad$ putting in place appropriate restrictions for overspending during the execution of the budget, and gradually introducing limits on multi-annual expenditure commitments. 


\section{Appendix I: Budget Institutions Evaluation Framework}

\section{A. Understanding the Fiscal Outlook and Challenges}

\section{Comprehensive, Timely, and Credible Fiscal Reporting}

a. Do the central government annual financial statements consolidate all central government entities? Criteria: Not met $=$ no annual financial statements are produced; Partly met=annual financial statements cover only the budget; Fully met=annual financial statements cover all of central government.

b. Do central government annual financial statements include assets and liabilities? Criteria: Not met $=$ no balance sheet is produced; Partly met $=a$ balance sheet is produced but not all assets or liabilities are included; Fully met=a comprehensive balance sheet, which includes nonfinancial as well as financial assets, is prepared.

c. Are financial statements audited by an independent supreme audit institution? Does the auditor certify whether the statements represent a true and fair view of the government's overall financial position? Criteria: Not met=no external audit is publicly available; Partly met=there is a published audit but the external auditor does not issue an overall opinion as to whether the statements represent a true and fair view of the government's financial position; Fully met=there is a published external audit in which the auditor gives an opinion as to whether the accounts represent a true and fair view of the government's financial position.

d. Are annual financial statements published and audited in a timely manner? Criteria: Not met=financial statements are published more than six months after the end of the financial year; Partly met= financial statements are published within six months OR audited within nine months of the end of the financial year; Fully met=financial statements are published and audited within six months of the end of the financial year.

e. Are government financial statistics comprehensive? Criteria: Not met=government financial statistics are not produced or cover only central government; Partly met=government financial statistics for central and general government are produced; Fully met=government financial statistics for the whole of the public sector are produced.

f. Are government financial statistics produced by an independent statistics office consistent with an international standard? Criteria: Not met $=$ neither; Partly met=government financial statistics are produced by an independent office or in line with an international standard, but not both; Fully met=government financial statistics are produced by an independent office and in line with SNA93, ESA95, or GFS2001.

\section{Robust Macroeconomic and Fiscal Forecasting}

a. Does the government publish macroeconomic forecasts in the budget documents? Criteria: Not met $=$ no annual or medium-term macro projections are published; Partly met=the government publishes annual (one-year ahead) macro projections; Fully met $=$ medium-term macro projections are published in or alongside the budget documents. 
b. Does the government publish forecasts of all major fiscal aggregates (e.g., revenues, expenditures, balance, debt) inclusive of all major economic assumptions (e.g. GDP, inflation, exchange rate, oil price, unemployment)? Criteria: Not met $=$ no annual or mediumterm projections are published or they are published without assumptions; Partly met=oneyear ahead fiscal projections are published with assumptions; Fully met=medium-term fiscal projections and assumptions are published.

c. Is there a mid-year budget update? Criteria: Not met=There is no requirement that the government publish an update half-way through the budget year, with updated projections of key fiscal variables. Partly met=the government publishes a mid-year budget update with projections for expected revenue, expenditure and balance, but only covering the budget year. Fully met=the government publishes a mid-year update with projections of key fiscal variables for the budget year and over the medium term.

d. Is there a regular quality control through ex post comparison of previous forecasts with actual outturn of key macroeconomic and fiscal aggregates? Criteria: Not met $=$ there is no ex post comparison of the government's macroeconomic or fiscal forecasts. Partly met $=$ there are ex post comparisons of either macroeconomic or fiscal forecasts with the outturn. Fully met=there are comparisons of both the government's macroeconomic and fiscal forecasts with the outturn.

e. Are long-term fiscal projections (i.e., for at least 20 years) prepared by government and published at least every three years? If yes, do they include the impact of demographic factors? Do they look at a range of demographic scenarios? Do they also look at other factors (e.g., health care costs) affecting long-term fiscal sustainability)? Criteria: Not met=no longterm projections published or published infrequently (at intervals exceeding three years); Partly met=government publishes long-term budgetary projections at least every three years, but only on the basis of demographic variables; Fully met=comprehensive long-term fiscal sustainability reports are prepared at least every three years, and look at either a range of demographic scenarios or utilize one or more additional factors (e.g., health care costs, climate change, etc.).

\section{Fiscal Risk Management}

a. Are the main fiscal risks (macro-fiscal, guarantees, international commitments, social commitments, public-private partnerships, and legal claims) discussed and quantified in the budget documents? Criteria: Not met=fiscal risks are not discussed in the budget documents; Partly met=there is some discussion of fiscal risks in budget documents; Fully met=budget documentation includes a comprehensive and quantified fiscal risk statement.

b. Are new contingent liabilities subject to parliamentary approval? Criteria: Not met=parliamentary approval is not sought for new contingent liabilities; Partly met=parliamentary approval is sought for new guarantees only; Fully met=parliamentary approval is sought for new guarantees and other significant, predictable and quantifiable contingent liabilities.

c. Are alternative medium-term budget scenarios presented in the annual budget documents? Criteria: Not met $=$ no alternative medium-term scenarios are discussed; Partly met=alternative medium term macroeconomic scenarios are discussed but their consequences 
for the major fiscal aggregates are not presented; Fully met=alternative medium-term scenarios and their implications for the main fiscal aggregates are presented as part of the annual budget documentation.

d. Are the risks associated with government assets examined at the same time as those relating to government debt and other liabilities? Criteria: Not met=the government does not prepare a medium-term debt management strategy, nor assesses the risks associated with government assets; Partly met=the government prepares a medium-term debt management strategy, including analysis of debt-related risks, but does not include asset-related risks; Fully met=the government publishes a medium-term debt management strategy, including analysis of debt-related risks and risks from government assets.

\section{Independent Fiscal Agencies}

a. Is there an independent agency responsible for preparing macroeconomic and fiscal forecasts that provide the public with alternative projections to those in the draft budget (or at least examines the assumptions on which the government's projections are based)? Criteria: Not met $=$ no independent projections are prepared and assumptions are not scrutinized; Partly met=an independent agency prepares either macroeconomic forecasts or fiscal forecasts, or at least examines the assumptions on which the government's projections are based; Fully met $=$ an independent agency prepares both macroeconomic and fiscal forecasts.

b. Is there an independent agency charged with evaluating the government's ex ante fiscal objective and/or fiscal policy? Criteria: Not met $=$ no independent evaluation of the government's fiscal objectives and/or policy; Partly met=an independent agency evaluates the government's fiscal objective and/or policy, but its advice is confidential to the executive; Fully met=an independent agency evaluates the government's fiscal objective and/or policy, and its advice is published.

c. Is there a regular quality control through ex ante comparison with other forecasting institutions of the macroeconomic assumptions underpinning the budget? Criteria: Not met=there is no ex ante comparison of the government's macroeconomic or fiscal forecasts with other forecasting institutions; Partly met=There are ex ante comparisons of either macroeconomic or fiscal forecasts with other forecasting institutions. Fully Met=There are ex ante comparisons of both the government's macroeconomic and fiscal forecasts with those of other forecasters.

d. Is there an independent agency charged with evaluating the government's ex post performance against its fiscal objectives? Criteria: Not met=no independent ex post evaluation of government fiscal performance; Partly met=an independent agency evaluates the government's ex post fiscal performance, but its views is regarded as advisory only; Fully met=there is an independent agency that is charged with providing an authoritative evaluation (i.e., one that requires follow-up) of the government's performance against its fiscal targets, objectives or rules. 


\section{Formulating a Credible Fiscal Plan}

\section{Clear and Transparent Medium-Term Fiscal Objectives}

a. Is there a precise and time-bound medium-term fiscal objective? Criteria: Not met $=$ neither the precise value nor the time period for the fiscal target is specified (alternatively, medium-term fiscal objectives are not disclosed); Partly met=either the precise value or time-period is specified; Fully met=both the precise value and time period are specified.

b. Does the government routinely report on performance against its fiscal objectives? Criteria: Not met=there is no reporting against the government's fiscal objectives; Partly met=there is periodic, ad hoc reporting of the government's performance against its fiscal objectives; Fully met=the government reports performance against its fiscal objectives at least annually.

c. Are the fiscal objectives expressed in terms of a permanent numerical fiscal rule? Criteria: Not met=there is no fiscal rule or it frequently changes; Partly met $=$ a fiscal rule exists and has been stable over the past three years; Fully met $=$ the fiscal rule has been enshrined in law.

d. Is there an adequate escape clause for the fiscal rule framework? Criteria: Not met=exceptions to the fiscal rule take place, but are not allowed by the legal framework; Partly met=exceptions to the fiscal rule framework take place on the basis of an escape clause which allows for considerable discretion; Fully met=exceptions to the fiscal rule are tightly defined by law and require approval by parliament.

e. Do fiscal rules accommodate the business cycle? Criteria: Not met=the fiscal rule framework in place does not seem linked to this objective; Partly met=implementation of the fiscal rule framework is designed to avoid pro-cyclicality (for example, by using a safety margin in targeting); Fully met=the fiscal rule framework is explicitly designed to accommodate the impact of the business cycle?

\section{Medium-term Budget Framework}

a. Is the annual budget prepared within a set of medium-term revenue and expenditure projections? Criteria: Not met=there are no medium-term estimates of revenue or expenditure in the budget documentation; Partly met=budget documentation includes multiyear estimates for the main categories of revenue and expenditure; Fully met=budget documentation includes multi-year estimates for each major revenue category and mediumterm costings of expenditure by sector, ministry or program.

b. Are there binding multi-year restrictions on aggregate expenditure? Criteria: Not met=there are no multi-year objectives or restrictions on aggregate expenditure; Partly met=there is an explicit multi-year objective for aggregate expenditure but it applies only to the forecast (which can subsequently be revised); Fully met=there is a binding multi-year restriction on the outturn for aggregate expenditure and the spending ceilings remain fixed for at least two years. 
c. Does the government provide a clear and consistent statement of its medium-term ministerial, sectoral or programmatic priorities within the ceiling on total expenditure?

Criteria: Not met $=$ detailed medium-term expenditure estimates are mechanistic projections that do not reflect announced sectoral priorities; Partly met=detailed medium-term expenditure estimates reflect the government sectoral priorities but there is no reconciliation of changes in sectoral allocations from year to year; Fully met=the government provides detailed medium-term sectoral expenditure estimates with a full explanation of any changes from year to year.

d. Do multi-year expenditure ceilings cover the majority of central government expenditure? Criteria: Not met=there are no multi-year expenditure ceilings or they cover less than 50 percent of central government expenditure; Partly met=the medium-term expenditure ceilings cover more than 50 percent of central government expenditure; Fully met $=$ the medium-term expenditure ceilings cover more than 75 percent of central government expenditure.

e. Do fiscal projections separately identify the impact of current versus new policies (revenue and expenditure measures)? Criteria: Not met $=$ no; Partly met $=$ for some but not all new revenue and expenditure measures or no consolidated presentation of fiscal impact of new polices; Fully met=budget documents present a consolidated summary of the fiscal impact of all proposed new revenue and expenditure measures.

\section{Performance-Orientation of the Budget}

a. Does the annual budget include a program classification? Are programs the basis for legislative appropriation of expenditure? Criteria: Not met=the annual budget document does not include a program classification; Partly met=the annual budget document includes a program classification for information but this is not the basis for legislative appropriation; Fully met=the annual budget documentation includes program classification and this is the basis for legislative appropriation.

b. Are there objectives and targets associated with each major expenditure program? Is the achievement of performance objectives and targets monitored at least annually? Criteria: Not met=there are no performance objectives or targets for expenditure; Partly met=performance targets or objectives are established but not systematically monitored; Fully met $=$ performance targets and objectives are set with systematic reporting on progress on at least an annual basis.

c. Are there comprehensive sector reviews on a regular basis? Criteria: Not met=expenditure reviews are not part of the budget process; Partly met=expenditure reviews are infrequent or incomplete (rolling reviews are not complete or comprehensive reviews are ad hoc and/or happen more than every three years); Fully met=all expenditure programs are systematically reviewed on either a comprehensive (at least once every three years) or rolling basis (at least 20 percent per year). 


\section{Intergovernmental Financial Arrangements}

a. Are medium-term general government projections prepared with an explanation of the contributions of each sector/level of government to total, balance and debt? Criteria: Not met=there is only a year-ahead forecast or a medium-term forecast of the budget or the central or federal government. Partly met=while there is a medium-term projection of the general government or public sector, this forecast is not broken down into the respective contribution of individual sectors/level of government (budget, social security funds, extrabudgetary funds, local government and state-owned enterprises. Fully met=medium-term projections of key fiscal variables are decomposed into the contribution of individual sectors/levels of government.

b. Is (are) the fiscal objective(s) comprehensive in scope? Criteria: Not met=the fiscal objective covers only the central government budget (or no objective); Partly met=the fiscal objectives covers the entire central government sector, inclusive of extra-budgetary activities controlled by central government; Fully met=covers the general government sector or the public sector.

c. Are sub-national governments subject to clear fiscal rules and centralized enforcement mechanisms? Criteria: Not met=there are no fiscal rules for sub-national governments; Partly met=there are fiscal rules for sub-national governments but no centralized sanctions or enforcement mechanisms; Fully met=there are fiscal rules for subnational governments and centralized sanctions or enforcement mechanisms in the event of non-compliance.

d. Are there mechanisms to coordinate fiscal policy among layers of government? Criteria: Not met $=$ central or federal government has no interaction with sub-national government on fiscal policy; Partly met=central or federal government has regular information exchange on fiscal policy with sub-national government; Fully met=there is a legal framework for coordinating and sharing the burden of fiscal policy between layers of government.

\section{Implementing the Fiscal Strategy through the Budget Process}

\section{Budget Unity}

a. Does the central government budget cover a majority of central government expenditure? Criteria: Not met=the budget, unemployment and social security funds or spending cover less than 80 percent of central government expenditure; Partly met=the budget, unemployment and social security funds or spending cover more than 80 but less than 90 percent of central government expenditure; Fully met=the budget, unemployment and social security funds or spending cover more than 90 percent of central government expenditure.

b. Is all central government budget expenditure authorized annually? Criteria: Not met $=$ more than 40 percent of the budget spending is authorized by standing appropriations or separate legislation, not requiring annual approval by parliament (e.g. interest payments or fees to international organizations); Partly met=less than 40 percent, but more than 10 
percent, of the budget spending is authorized by standing appropriations or separate legislation, not requiring annual approval by parliament; Fully met=more than 90 percent of the budget spending requires annual authorization by parliament.

c. Are major tax expenditures quantified and published, e.g. in the annual budget? Is there a mechanism for controlling the size of tax expenditures? Criteria: Not met $=$ there is no quantification of tax expenditures and no control on their size; Partly met=there is an annual quantification of tax expenditures but no control on their size; Fully met $=$ there is quantification and annual reporting of all major tax expenditures, and a control on their size.

\section{Top-Down Approach to Budget Preparation}

a. Is a limit on annual aggregate expenditure and the allocation to broad sectors or to ministries approved by the government before the discussion (within the executive) of the detailed allocations for spending? Criteria: Not met=ex ante limits on annual spending are not agreed at an early stage of budget preparation within the executive; Partly met=ex ante limits on aggregate expenditures (but not for sectors/ministries) are agreed at an early stage of budget preparation within the executive; Fully met $=$ ex ante limits on both aggregate and sectoral/ministerial spending are agreed at an early stage of budget preparation and prior to receipt of budget submissions from line ministries.

b. Are aggregate limits and sector or ministry allocations respected in the preparation of the budget within the executive? Criteria: Not met=ex ante ceilings are not respected; Partly met $=$ ex ante ceilings are sometimes respected; Fully met $=$ ex ante ceilings are almost always respected.

c. Are earmarking of revenue to budgetary expenditure relatively limited? Criteria: Not met $=$ central government revenue earmarking exceed 30 percent of total central government expenditure; Partly met=central government revenue earmarking are between 10 and 30 percent of central government expenditure; Fully met=revenue earmarking are less than 10 percent of central government expenditure.

d. Are all major revenue or expenditure decisions taken as part of the annual budget preparation processes within the executive? Criteria: Not met=major revenue or expenditure decisions are often taken outside the annual budget preparation processes; Partly met=major revenue and expenditure decisions are sometimes taken outside the annual budget preparation processes; Fully met=major revenue and expenditure decisions are seldom taken outside the annual budget preparation processes and supplementary budgets are rare and/or limited in size (less than 3 percent of the budget).

\section{Constraints on Parliamentary Budget Approval}

a. Do institutional arrangements ensure ownership of the medium-term fiscal strategy by the parliament? Criteria: Not met=there is no separate budget orientation debate and parliament does not endorse a medium-term fiscal target or objective; Partly met $=$ there is either a separate budget orientation debate or parliament endorses a medium-term fiscal target or objective strategy, but not both; Fully met=there is a separate budget orientation debate and parliament explicitly endorses a medium-term fiscal target or objective. 
b. Are there (self-imposed) limits on the legislature's right to amend the government's draft budget? Criteria: Not met= there are no limits on the right of parliament to amend the government's draft budget; Partly met=parliament can introduce fiscally neutral amendments to the budget; Fully met=parliament can change the composition of expenditures, but not increase the proposed budget deficit, nor total expenditures (alternatively, parliament must approve the government's proposed budget, without any modification).

c. Is the annual budget approved in a top-down sequence, i.e., does parliament first approve budget aggregates (total revenues, total expenditures, the fiscal balance and/or (net) borrowing) before it approves detailed spending? Criteria: Not met=parliament does not first approve the budget aggregates before voting on detailed spending; Partly met=parliament first approves the budget aggregates, but subsequent changes in budget aggregates are still possible; Fully met=parliament first approves the budget aggregates, then votes on the detailed expenditures within the approved top down constraints on total spending and revenue.

d. Is the budget approved in a timely manner? Criteria: Not met=there are no clear rules regarding the timing of final approval of the budget; Partly met=there is a legal requirement that the budget be approved within three months after the start of the fiscal year; Fully met=there is a legal requirement that a budget is approved before the start of the fiscal year.

\section{Constrained Flexibility in Budget Execution}

a. Are there restrictions on overspending during the execution of the annual budget? Criteria: Not met=the government is not required to go back to parliament before the end of the current fiscal year when spending exceeds annual appropriations; Partly met=the government is required to submit a supplementary budget to parliament if total spending exceeds annual appropriations; Fully met=in case of overspending against the total annual appropriations, the government is required to submit a supplementary budget showing how overspending of total expenditure will be offset through reductions in other appropriations.

b. Are there restrictions on appropriations that are carried over from one year to the next? Criteria: Not met=there are no restrictions on carried-over appropriations; Partly met=there are restrictions on the types of expenditure subject to carry-over of appropriation, but no limit on the size of carried-over balances into subsequent years or draw-down of previously carried-over balances; Fully met $=$ carry-over is not permitted or the government imposes a ceiling on the size of annual carry-over or on draw-down of previously carriedover balances.

c. Are there reserves or other arrangements for spending on unforeseen contingencies, with clear rules for spending from the reserve? Criteria: Not met=no reserves or contingency arrangements are in place; Partly met=there are reserves or contingency arrangements for specific expenditure categories; Fully met=there is a sizeable general contingency reserve (e.g., 1 to 3 percent of total expenditure) in the annual budget, with clear rules for accessing the reserve.

d. Is the finance minister (the executive) mandated to defer or cut expenditure, i.e., not fully implement the approved budget? Criteria: Not met=expenditures cannot be deferred or 
cut without prior approval of parliament; Partly met=expenditures can be deferred or cut, without prior approval of parliament, up to a certain limit; Fully met=budget appropriations can be deferred or cut by the executive, without limit.

e. Are there limits or controls on a line ministry's ability to enter into multi-annual expenditure commitments? Criteria: Not met $=$ there are no limits or controls on multi-annual expenditure commitments by line ministries; Partly met=there are limits or controls on some categories of multi-annual expenditure commitments by line ministries; Fully met=there are comprehensive limits or controls on all types of multi-annual expenditure commitments by line ministries. 


\section{Appendix II: PEFA Scoring Methodology}

\section{Aggregate expenditure out-turn compared to original approved budget}

A. In no more than one out of the last three years has the actual expenditure deviated from budgeted expenditure by an amount equivalent to more than $5 \%$ of budgeted expenditure.

B. In no more than one out of the last three years has the actual expenditure deviated from budgeted expenditure by an amount equivalent to more than $10 \%$ of budgeted expenditure.

C. In no more than one of the last three years has the actual expenditure deviated from budgeted expenditure by more than an amount equivalent to $15 \%$ of budgeted expenditure.

D. In two or all of the last three years did the actual expenditure deviate from budgeted expenditure by an amount equivalent to more than $15 \%$ of budgeted expenditure.

\section{Composition of expenditure out-turn compared to original approved budget}

A. Variance in expenditure composition exceeded $5 \%$ in no more than one of the last three years.

B. Variance in expenditure composition exceeded $10 \%$ in no more than one of the last three years.

C. Variance in expenditure composition exceeded $15 \%$ in no more than one of the last three years.

D. Variance in expenditure composition exceeded $15 \%$ in at least two of the last three years. 


\section{References}

Alesina, Alberto, Ricardo Hausmann, Rudolf Hommes, and Ernesto Stein, 1999, "Budget Institutions and Fiscal Performance in Latin America," Journal of Development Economics, Vol. 59, pp. 253-273.

Allen, Richard, 2013, "Challenges of Reforming Budgetary Institutions in Developing Countries", in Marco Cangiano, Teresa Curristine, and Michel Lazare (Eds.) Public Financial Management and Its Emerging Architecture, Washington, D.C.: International Monetary Fund.

Andrews, Matt, 2013, The Limits of Institutional Reform in Development: Changing Rules for Realistic Solutions, Cambridge, Cambridge University Press.

Dabla-Norris, Era, Richard Allen, Luis-Felipe Zanna, Tej Prakash, Eteri Kvintradze, Victor Lledo, Irene Yackovlev, and Sophia Gollwitzer, 2010, "Budget Institutions and Fiscal Performance in Low-Income Countries". Working Paper 10/80. (Washington: International Monetary Fund).

De Haan, Jakob, Wim Moessen, and Bjorn Volkerink, 1999, "Budgetary ProceduresAspects and Changes: New Evidence for Some European Countries," in JamesPoterba and Jürgen von Hagen (eds.) Fiscal Institutions and Fiscal Performance, Chicago University Press.

De Renzio, Paolo, 2009, “Taking Stock: What Do PEFA Assessments Tell Us About PFM Systems Across Countries", Working Paper, Overseas Development Institute.

De Renzio, Paolo, 2013, “Assessing and Comparing the Quality of Public Financial Systems: Theory, History and Evidence", in Richard Allen, Richard Hemming and Barry Potter (Eds.) International Handbook of Public Financial Management, Palgrave Macmillan.

Diamond, Jack, 2013. Good Practice Note on Sequencing Public Financial Management (PFM) Reform; and Guidelines for Sequencing PFM Reform, PEFA Secretariat.

Filc, Gabriel, Carlos Scartascini, 2007, "Budgetary Institutions”. In Eduardo Lora (Ed.) “The State of State Reform in Latin America". Inter-American Development Bank. Washington.

Gollwitzer, Sophia, 2011, "Budget Institutions and Fiscal Performance in Africa", Journal of African Economies, Vol. 20, number 1, pp. 111-152.

Hallerberg, Mark, Rolf Strauch und Jürgen von Hagen, 2009, Fiscal Governance: Evidence from Europe. Cambridge: Cambridge University Press.

— Sami Yläoutinen, 2010, "Political Power, Fiscal Institutions and Budgetary Outcomes in Central and East European Countries", Journal of Public Policy 30:1, 45-62. 
Harris, Jason, Richard Hughes, Gösta Ljungman, and Carla Sateriale, 2013, "Medium-Term Budget Frameworks in Advanced Economies: Objectives, Design, and Performance" in Marco Cangiano, Teresa Curristine, and Michel Lazare (Eds.) Public Financial Management and Its Emerging Architecture, Washington, D.C.: International Monetary Fund.

International Monetary Fund, 2014, "Budget Institutions in G-20 Countries: An Update", April 7, 2014, (Washington: International Monetary Fund).

Olden, Brian, Duncan Last, Sami Yläoutinen, and Carla Sateriale, 2012, "Fiscal Consolidation in Southeast European Countries: The Role of Budget Institutions," IMF Working Paper 12/113 (Washington: International Monetary Fund).

Prakash, Tej and Ezequiel Cabezon, 2008, "Public Financial Management and Fiscal Outcomes in Sub-Saharan African Heavily-Indebted Poor Countries", IMF Working Paper 08/217 (Washington: International Monetary Fund).

Von Hagen, Jürgen, 1992, "Budgeting Procedures and Fiscal Performance in the European Communities," European Commission Economic Papers No. 96, (Brussels: European Commission).

- and I.J. Harden, 1996, "Budget Processes and Commitment to Fiscal Discipline," IMF Working Paper 96/78 (Washington: International Monetary Fund). 